\title{
RECLAMAÇÕES FRAUDULENTAS A PARTIR DE CARACTERÍSTICAS DA CULTURA BRASILEIRA: UM ESTUDO QUALITATIVO UTILIZANDO A TÉCNICA PROJETIVA ${ }^{1}$
}

\author{
Thuanne Figueiredo Baptista ${ }^{2}$ \\ Marcus Wilcox Hemais ${ }^{3}$
}

http://dx.doi.org/10.1590/1413-2311.275.94047

\section{RESUMO}

Reclamações de consumidores podem ser feitas por diversos motivos, mas majoritariamente, ocorrem a partir de episódios negativos de consumo. Entretanto, há indivíduos que realizam reclamações a empresas sem necessariamente estarem insatisfeitos. A essa conduta, dá-se o nome de reclamação fraudulenta, que ocorre quando a finalidade do consumidor em realizar a reclamação visa algum lucro monetário ou social à custa da empresa. Apesar da relevância do tema, há poucos estudos a seu respeito na área de marketing, principalmente no Brasil. À frente desse quadro, o presente estudo tem o objetivo de analisar como aspectos relacionados a características da cultura brasileira influenciam a forma como consumidores interpretam a prática de reclamações fraudulentas. Para isso, foi realizada uma pesquisa qualitativa, por meio de entrevistas em profundidade com 27 consumidores, pautadas pelo uso da técnica projetiva. A análise dos dados indica diferentes reações dos entrevistados a reclamações fraudulentas, apresentando sentimentos distintos no que se refere aos comportamentos oportunistas. Foi possível perceber que existe uma relação entre as características da cultura brasileira e as reclamações fraudulentas, que giram em torno da ideia da casa e da rua, do

\footnotetext{
${ }^{1}$ Recebido em27/6/2019, aprovado em 22/1/2020.

2 Pontifícia Universidade Católica do Rio de Janeiro - Programa de Pós-Graduação em Administração de Empresas; Rio de Janeiro - RJ (Brasil); http://orcid.org/0000-0002-4387-0351; thuannebaptista@ gmail.com

${ }^{3}$ Pontifícia Universidade Católica do Rio de Janeiro - Programa de Pós-Graduação em Administração de Empresas; Rio de Janeiro - RJ (Brasil); http://orcid.org/0000-0001-9181-8446; marcus.hemais@iag.puc-rio.br
}

(c) $(1)$ REAd | Porto Alegre - Vol. 26 - N. ${ }^{\circ} 1$ - Janeiro / Abril 2020 - 81-113. 
‘jeitinho brasileiro', da malandragem, além da ligação entre religião e comportamentos (anti)éticos.

Palavras-chave: Reclamações Fraudulentas. Comportamentos Oportunistas. Consumidores Antiéticos. Cultura Brasileira. Jeitinho Brasileiro.

\section{FRAUDULENT COMPLAINTS THROUGH CHARACTERISTICS OF BRAZILIAN CULTURE: A QUALITATIVE STUDY USING PROJECTIVE TECHNIQUE}

Consumers complaints can be made for several reasons, but mostly originate from negative episodes of consumption. However, there is a group of individuals who make complaints to companies without necessarily being dissatisfied. This behavior is called fraudulent complaints, which occurs when the purpose of the consumer in making the complaint is of monetary nature or searching for social profit at the expense of the company. Despite the relevance of the theme, there are few studies about it in the area of marketing, especially in Brazil. Ahead of this scenario, the present study aims to analyze how aspects related to the characteristics of Brazilian culture influence the way consumers interpret the practice of fraudulent complaints. For this, a qualitative research was carried out, using in-depth interviews with 27 consumers, guide by the use of the projective technique. The analysis of the data indicates different reactions of respondents to fraudulent complaints, presenting different feelings regarding opportunistic behavior. It was possible to perceive that there is a relationship between the characteristics of Brazilian culture and fraudulent complaints, which revolve around the idea of the "casa" and the "rua", "jeitinho brasileiro", the "malandragem", besides the link between religion and (un)ethical behavior.

Keywords: Fraudulent complains. Opportunistic Behavior. Unethical Consumers. Brazilian Culture. 'Brazilian Way'.

\section{RECLAMACIONES FRAUDULENTAS A PARTIR DE LAS CARACTERÍSTICAS DE LA CULTURA BRASILEÑA: UN ESTUDIO CUALITATIVO USANDO LA TÉCNICA PROYECTIVA}

Las reclamaciones de consumidores pueden ser hechas por diversos motivos, pero mayoritariamente, ocurren a partir de episodios negativos de consumo. Sin embargo, hay 
individuos que realizan reclamaciones a empresas sin necesariamente estar insatisfechos. A esta conducta, se da el nombre de reclamación fraudulenta, que ocurre cuando la finalidad del consumidor en realizar la reclamación busca algún beneficio monetario o social a costa de la empresa. A pesar de la relevancia del tema, hay pocos estudios a su respecto en el área de marketing, principalmente en Brasil. Al frente de este cuadro, el presente estudio tiene el objetivo de analizar cómo aspectos relacionados con las características de la cultura brasileña influyen em la forma en que los consumidores interpretan la práctica de reclamaciones fraudulentas. Para esto, se realizó una investigación cualitativa, por medio de entrevistas en profundidad con 27 consumidores, pautadas por el uso de la técnica proyectiva. El análisis de los datos indica diferentes reacciones de los entrevistados a reclamaciones fraudulentas, presentando diferentes sentimentos com respecto a los comportamientos oportunistas. Fue posible darse cunta de que existe uma relación entre las características de la cultura brasileã y las reclamaciones fraudulentas, que giram em torno a la ideia de la casa y la calle, el 'camino brasileño', el engano, así como la conexión entre la religión y los comportamientos (poco) éticos.

Palabras clave: Reclamaciones Fraudulentas. Comportamientos Oportunistas. Consumidores Antiéticos. Cultura Braileña. 'Estilo Brasileño'.

\section{INTRODUÇÃO}

Segundo o Sistema Nacional de Informações de Defesa do Consumidor (Sindec) (SECRETARIA NACIONAL DO CONSUMIDOR, 2018), ocorreram uma média de 2.463.856 atendimentos por ano nos Procons do Brasil, entre 2015 e 2017, sendo que 84,2\% desses foram advindos de algum tipo de reclamação ou denúncia de consumidores em relação a um equívoco vivenciado com empresas. Em geral, tais reclamações são registradas no Sindec considerando que foram geradas a partir de experiências ruins de consumo. Entretanto, o que ocorre quando uma queixa não é oriunda de um processo de insatisfação?

Segundo Reynolds e Harris (2005), existem consumidores que fazem reclamações injustificadas a empresas, sem que tenham vivenciado falhas de serviços ou produtos, não estando, na verdade, insatisfeitos. Segundo os autores, essa prática é mais comum do que se imagina, pois sua pesquisa mostra que consumidores admitem já terem realizado reclamações fraudulentas em diversas ocasiões no passado. 
Nos últimos anos no Brasil, cresce o número de consumidores que têm reclamado sobre empresas buscando seus direitos tanto em organizações de defesa do consumidor - entre 2011 e 2018, por exemplo, aumentou de 1,6 milhão para 2,2 milhões o número de atendimentos a consumidores nos Procons do país (SECRETARIA NACIONAL DO CONSUMIDOR, 2011; 2018) - quanto na internet, principalmente em sites de reclamação, tais como o Portal do Consumidor, que teve um aumento de $30 \%$ de atendimentos entre janeiro de 2018 e janeiro de 2019 (GOVERNO FEDERAL, 2019). Cogitar que ao menos uma parte dessas reclamações possa ser fraudulenta, seguindo o raciocínio de Reynolds e Harris (2005), não seria um absurdo, até porque, dada a grande instabilidade econômica do país, consumidores brasileiros têm nutrido um sentimento de que não podem prejudicar o seu padrão de consumo e, portanto, deveriam se aproveitar de empresas para manter tal status (MELO; VALE; CORRÊA, 2018; MOLINA; PEPECE, 2018).

Possivelmente por causa desse tipo de ação fraudulenta, consumidores brasileiros que verdadeiramente se sentem insatisfeitos temem que suas queixas sejam interpretadas como atos de 'malandragem' ou tentativas de usar o 'jeitinho brasileiro' para conseguir alguma vantagem sobre a empresa reclamada (CHAUVEL, 2000). Por isso, em diversos casos assumem que prefeririam maneiras mais simples de resolver seus problemas do que a forma burocrática convencional de precisar se dirigir à empresa e reclamar (HEMAIS; CASOTTI, 2014).

Essa característica cultural do brasileiro associada à reclamação (CHAUVEL, 2000) pode ser mais bem entendida ao se analisar a visão de DaMatta sobre a cultura do Brasil. Da Matta (1986) discute, por meio de contrastes e antagonismos, que enquanto é em casa (ou no ambiente conhecido como lar) onde ocorre o discurso conservador, defensor dos tradicionais valores morais, também é dentro de casa, e desde cedo, que é apresentado o tradicional 'jeitinho brasileiro'. Esse comportamento social é caracterizado como uma forma de satisfazer vontades e desejos, às vezes de difícil acesso, por meio do uso de determinados recursos pessoais nem sempre acessíveis a todos. Enquanto que, em alguns momentos, o jeitinho pode ser uma característica positiva de um indivíduo, pois é capaz de resolver problemas por esforços próprios, em outros é associado a uma transgressão de normas ou regras essenciais, para um comportamento de bom senso ou coletividade.

No entanto, é no eixo impessoal, caracterizado por DaMatta (1986) como 'rua', no qual o indivíduo não possui aporte parental, que ocorrem tentativas de articular estratégias de navegação social a partir do 'jeitinho', fazendo assim com que esses indivíduos mantenham 
ou conquistem seus interesses. É na 'rua', portanto, que se busca a melhora da 'casa'. Todavia, não há necessariamente uma coerência nessa relação; o que é feito na 'rua' não necessariamente é aceito em 'casa' (DAMATTA, 1989; LOURENÇO, 2014).

Entende-se, portanto, que para a compreensão da relação entre empresas - a partir de como lidam com reclamações fraudulentas - e o consumidor, é necessário ter como pano de fundo a cultura das pessoas envolvidas nessas relações. Isso é verdade principalmente no contexto brasileiro, que é caracterizado por ser uma sociedade na qual comumente vigoram tanto os códigos relacionais, como os impessoais (LOURENÇO, 2014).

Essas características relacionadas aos consumidores brasileiros são pouco discutidas na literatura de marketing, mais especificamente na de reclamações fraudulentas. De uma maneira geral, essa literatura pouco discute a influência de características da cultura de um país sobre a adoção desse tipo de queixa (PARK; KIM; O’NEILL, 2014), embora, no Brasil (mas não particularmente somente no Brasil), esse aspecto se mostre fundamental nas ações diárias de sua população (DAMATTA, 1983).

Diante do contexto apresentado, o presente estudo tem o objetivo de analisar como aspectos relacionados a características da cultura brasileira influenciam a forma como consumidores interpretam a prática de reclamações fraudulentas. Para isso, foi realizada uma pesquisa qualitativa com 27 consumidores, na qual utilizou-se a técnica projetiva para a coleta de dados.

Após os comentários introdutórios, o restante do artigo é dividido em mais cinco itens. O segundo e terceiro apresentam o referencial teórico do estudo, discutindo o comportamento de consumidores que realizam reclamações fraudulentas e a cultura brasileira. Em seguida, o quarto item discute a metodologia adotada. A análise dos dados é apresentada no quinto item. Por fim, no sexto item, as considerações finais são feitas.

\section{RECLAMAÇÕES FRAUDULENTAS DE CONSUMIDORES}

É comum que consumidores, diante de uma situação de insatisfação, reclamem com a empresa de onde consumiram determinado produto ou serviço. Estudos sobre reclamação de consumidores são encontrados na literatura de marketing, desde os anos 1970 (DAHL; PELTIER, 2015; SUOMI; JÄRVIEN, 2018), porém, somente a partir dos anos 2000, surgiram trabalhos que questionam a validade dessas reclamações (REYNOLDS; HARRIS, 2005; WIRTZ; KUM, 2004). Segundo Reynolds e Harris (2005), é possível caracterizar a 
falta de legitimidade de uma reclamação quando o consumidor intencionalmente e conscientemente faz uma reclamação sem ter uma experiência genuína de falha de serviço ou de insatisfação.

Discussões sobre reclamações fraudulentas começam a partir do estudo de Schmidt et al. (1999), que discutiram o comportamento de deshopping do consumidor, um tipo que se refere a uma compra que possui premeditadamente uma devolução já definida e inadequada de bens por razões diferentes das falhas reais no produto. Piron e Young (2000) também analisam essa questão, chamando o retorno de bens que cumpriram o propósito para o qual já foram comprados de 'Empréstimo de Varejo'. As definições dos dois termos mencionados anteriormente, deshopping e 'empréstimo de varejo', são semelhantes e seus estudos convergem em questões econômicas relevantes, como, por exemplo, não poder pagar por um produto, mas ainda assim querer tê-lo por alguns dias (SCHMIDT et al., 1999).

A partir do estudo de Schmidt et al. (1999), análises desse tipo de comportamento, demostraram que experiências passadas bem-sucedidas, controle da situação e intenção seriam determinantes para novas tentativas desse comportamento. Todavia, a insatisfação não era dada necessariamente com o produto, e também a partir de sentimentos de não pertencimento, ou de falta de poder econômico (KING; DENNIS, 2006; ROSENBAUM; KUNTZE; WOOLDRIDGE, 2011).

Com base nas discussões tratadas por Schmidt et al. (1999) e Piron e Young (2000), outras pesquisas começam a testar diferentes contextos, tentando entender fatores inibidores e incentivadores de engajamento em reclamações fraudulentas (KING; DENNIS, 2006; REYNOLDS; HARRIS, 2005). Destaca-se nesse momento, principalmente, a pesquisa de Rosenbaum e Kuntze (2003), em que relatavam a importância da anonimidade no engajamento nas reclamações fraudulentas.

Após esses trabalhos iniciais, o estudo de Reynolds \& Harris (2005) marcou a literatura sobre o tema, conseguindo mapear por meio de entrevistas com consumidores que praticavam reclamações fraudulentas quatro formas de reclamação, e seis tipos de motivações. A Figura 1, a seguir, apresenta o modelo dos autores. 


\section{Figura 1: Motivadores dos comportamentos ilegítimos de consumidores}

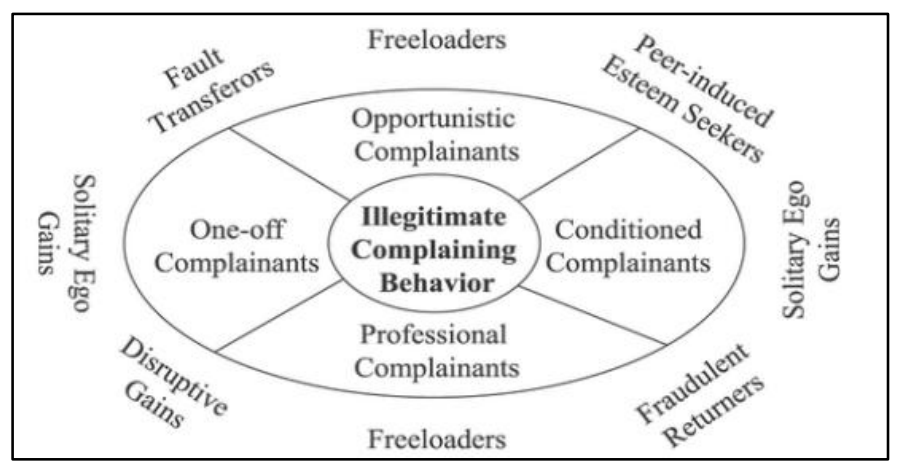

Fonte: Reynolds e Harris (2005)

As quatro formas de reclamação encontradas por Reynold e Harris (2005) são 'One-off Complainants', 'Conditioned Complainants', 'Professional Complainants', e'Opportunistic Complainants'. Na Tabela 1, a seguir, é possível observar como as quatro são entendidas, e perceber que se diferenciam a partir da frequência em que são feitas, variando de atos pouco frequentes para atos muito frequentes.

\section{Tabela 1 - Formas de Reclamação Fraudulenta}

\begin{tabular}{cl}
\hline $\begin{array}{c}\text { Formas de } \\
\text { Reclamação }\end{array}$ & \multicolumn{1}{c}{ Como os consumidores se comportam } \\
\hline $\begin{array}{c}\text { 'One-off } \\
\text { Complaints' }\end{array}$ & $\begin{array}{l}\text { Reclamantes dizem que somente adotaram reclamações fraudulentas uma vez e em uma } \\
\text { situação distinta, de maneira isolada, sentindo-se angustiados durante o episódio, } \\
\text { resultando em um sentimento de culpa posterior. }\end{array}$ \\
$\begin{array}{cl}\text { 'Conditioned } \\
\text { Complaints' }\end{array}$ & $\begin{array}{l}\text { Consumidores presenciaram reclamações fraudulentas, aprenderam como exercê-la e, } \\
\text { atualmente, a praticam de forma regular. }\end{array}$ \\
'Professional & $\begin{array}{l}\text { Caracteriza-se pela procura constante dos consumidores a uma situação na qual possam } \\
\text { fazer uma reclamação fraudulenta. Em geral, esse grupo é proativo e articulado. }\end{array}$ \\
Complaints' & $\begin{array}{l}\text { Consumidores reclamam tão somente quando percebem que podem obter uma vantagem } \\
\text { lucrativa. Usualmente, esses consumidores não adotavam reclamações fraudulentas no } \\
\text { passado. Porém, ao longo do tempo, passaram a querer tirar vantagem em qualquer } \\
\text { situação. }\end{array}$ \\
\hline
\end{tabular}
Fonte: Reynolds e Harris (2005).

A última forma de reclamação fraudulenta, 'Opportunistic Complaints', é a mais pesquisada em um contexto gerencial, uma vez que consumidores que a adotam tentam se beneficiar a partir de políticas de retorno - tais como devolução e troca de produtos em caso de quebra ou insatisfação do consumidor ou reembolso se o serviço estiver aquém das expectativas do cliente - deficientes, visto que não são claras ou bem definidas (BAKER; MAGNINI; PERDUE, 2012; PIRON; YOUNG, 2000). É importante destacar que o 
comportamento oportunista pode surgir a partir de um entendimento de que há mais benefícios do que custos em realizar tais reclamações (REYNOLDS; HARRIS, 2005) ou de fatores ambientais ou situacionais (KING; DENNIS, 2006).Além das quatro formas de reclamação fraudulenta, Reynolds \& Harris (2005) também identificaram as motivações por trás de tais reclamações. No total, são seis tipos de motivação, classificadas como, 'Freeloaders', 'Fraudulent Returners', 'Fault Transferors', 'Solitary Ego Gains', 'PeerInduced Esteem Seekers' e 'Disruptive Gains', e que são mais bem detalhadas na Tabela 2, a seguir. É possível observar que as motivações se diferenciam a partir de interesses financeiros a até melhora do ego, mostrando, assim, ser de compreensão mais complexa do que as formas anteriores.

\section{Tabela 2 - Motivações para Reclamação Fraudulenta}

\begin{tabular}{|c|c|}
\hline $\begin{array}{c}\text { Tipos de } \\
\text { Motivações }\end{array}$ & Como os consumidores se comportam \\
\hline 'Freeloaders' & $\begin{array}{l}\text { São principalmente motivados por ganhos monetários ( WIRTZ; KUM, 2004), que podem } \\
\text { advir em forma de descontos ou produtos. Costumam ser consumidores que têm interesse } \\
\text { em ganhos financeiros, mas não possuem problemas financeiro. }\end{array}$ \\
\hline $\begin{array}{l}\text { 'Fraudulent } \\
\text { Returners' }\end{array}$ & $\begin{array}{l}\text { São caracterizados como sendo consumidores que compram um produto e o retornam à loja } \\
\text { depois de os terem utilizado (PIRON; YOUNG, 2000; SCHMIDT et al., 1999). É comum } \\
\text { que essa decisão de retornar o produto seja feita antes da compra, mas não é incomum que } \\
\text { seja feita depois de sua compra e uso. Segundo Reynolds \& Harris (2005), costuma ser o } \\
\text { tipo mais comum de motivação. }\end{array}$ \\
\hline $\begin{array}{l}\text { 'Fault } \\
\text { Transferors' }\end{array}$ & $\begin{array}{l}\text { São motivados a transferir seus próprios erros para as empresas, exigindo que essa se } \\
\text { responsabilize financeiramente por erros que o próprio consumidor cometeu. }\end{array}$ \\
\hline $\begin{array}{l}\text { 'Solitary Ego } \\
\text { Gains' }\end{array}$ & $\begin{array}{l}\text { É uma motivação que destoa das anteriores, pois nessa o consumidor reclama com o } \\
\text { objetivo de enaltecer seus sentimentos e seu ego. Seu objetivo não é obter atenção de outras } \\
\text { pessoas enquanto realiza a reclamação, pois busca uma satisfação interna. }\end{array}$ \\
\hline $\begin{array}{l}\text { 'Peer-induced } \\
\text { Esteem } \\
\text { Seekers' }\end{array}$ & $\begin{array}{l}\text { É uma motivação que segue o mesmo modelo da 'Solitary Ego Gains', com a diferença de } \\
\text { que o consumidor motivado dessa forma possui interesse em chamar atenção de outras } \\
\text { pessoas (KHANTIMIROV, 2018; HARRIS; REYNOLDS, 2003) que o observam, que, em } \\
\text { geral, são pares ou membros da família. }\end{array}$ \\
\hline $\begin{array}{l}\text { 'Disruptive } \\
\text { Gains' }\end{array}$ & $\begin{array}{l}\text { É um tipo de motivação que leva consumidores a reclamarem somente para causar algum } \\
\text { tipo de ruptura ou confusão na empresa. Uma subcategoria desse grupo é formada por } \\
\text { pessoas que já tiveram algum problema com a loja ou com algum funcionário, e pretendem } \\
\text { se vingar de um alvo específico. }\end{array}$ \\
\hline
\end{tabular}


Fonte: Reynolds e Harris (2005).

É possível observar, portanto, que há um certo grupo de consumidores que vem adotando mudanças em seu comportamento quanto a reclamar com empresas, pelos mais diferentes motivos, e que não necessariamente o fazem dentro da legalidade/moralidade. Todavia, os estudos analisados não discutem o quanto características culturais podem influenciar esse tipo de comportamento e ajudar a explicar o que levaria um consumidor a se engajar com tal ato oportunístico. O presente trabalho, portanto, pretende jogar luz sobre essa questão, visando entender melhor a relação de características da cultura brasileira com reclamações fraudulentas.

\section{CARACTERÍSTICAS DA CULTURA BRASILEIRA: A 'CASA E A RUA', O 'JEITINHO BRASILEIRO', A ‘MALANDRAGEM’ E A RELIGIÃO}

$\mathrm{Na}$ presente seção, procurou-se detectar as principais características culturais observadas na sociedade brasileira. Claramente, este trabalho não tem a ambição de abranger todos os traços da cultura nacional, muito menos de esgotar os tantos entendimentos e enfoques sobre o tema. Decidiu-se, portanto, abordar o assunto a partir da perspectiva de um renomado pesquisador em cultura brasileira, mais especificamente Roberto DaMatta (1986, 1989).

A escolha por Da Matta deu-se em razão de sua crença de que é necessário entender a cultura brasileira sob um ponto de vista relacional, que se aproximaria da discussão sobre reclamações dada a forte influência que as relações entre consumidores e empresas e seus funcionários tem sobre a queixa (CHAUVEL, 2000). Segundo DaMatta (1989), o que perdura na cultura local não é a imagem do cidadão, ou do indivíduo, mas a malha de relações estabelecidas por um grupo do qual esse indivíduo faz parte. Por isso, a unidade cultural do Brasil baseada na relação extrapolou a esfera social e chegou às esferas políticas e jurídicas, legitimando um conjunto de intermédios que podem privilegiar indivíduos de acordo com suas relações.

A partir dessas ideias, serão utilizados três conceitos essenciais que o autor defende como características relevantes da cultura brasileira, a casa e a rua, o jeitinho brasileiro e a malandragem e a religião. A casa e a rua podem ser entendidas como dois espaços sociais que influenciam a vida social brasileira. Entende-se a 'casa' como uma ideia comum entre objeto, 
relações e valores, sendo uma coletividade que atua de forma bem definida e em conjunto. Com isso, as pessoas de dentro de uma 'casa' possuem um sentido de defesa convergente em relação aos bens materiais, mas também de proteção de membros mais frágeis. No contexto social, a 'casa' é entendida como de valores e realidades múltiplas, mas que convergem para uma moral conjunta, principalmente em aspectos de 'honra', 'vergonha' e 'respeito' (DAMATTA, 1989).

Já a 'rua', pode ser entendida como uma maneira pela qual o mundo é lido e interpretado, predominando a desconfiança e a insegurança. A tendência da 'rua' é ser revolucionária e revoltada, visto que seus indivíduos são anônimos ao resto do mundo, gerando uma insegurança comparada à 'casa', em que relações são mais estreitas e calorosas. Ou seja, a 'casa' e a 'rua' são espaços físicos que afetam os espaços sociais de maneiras diferentes em alguns momentos.

Um julgamento de ações do ponto de vista da 'casa' pode ser diferente de um julgamento da mesma ação do ponto de vista da 'rua'. No entanto, se o indivíduo se sente em 'casa' na 'rua', o julgamento pode ser ainda mais brando. O caráter conciliatório do brasileiro acontece quando ele encontra na 'rua' a 'casa', quando ele consegue ser coletivo onde ele geralmente é indivíduo. São espaços, portanto, onde é formada a sociabilidade brasileira (DAMATTA, 1989, 2000).

Por mais que a 'rua' seja permeada pelo eixo das leis impessoais, e a 'casa' se mantenha mais no domínio das relações pessoais, a 'casa' e a 'rua' também são irmãs. Elas pertencem a uma mesma instituição social, sendo apenas enviesadas por escolhas de posicionamentos pessoais, diferenciando ou complementando a experiência social brasileira (DAMATTA, 2000). O ponto principal entre o estudo tanto da 'casa', quanto da 'rua', é a necessidade de estudar a sociedade brasileira de forma aberta, sendo capaz de captar o movimento e a fluidez, sempre no sentido da relação e da conexão (DAMATTA, 1989, 2000).

O 'jeitinho brasileiro' é outra característica marcante da cultura brasileira. Pode ser entendido como uma forma de navegação social, que tem como objetivo reduzir relações de assimetria dentro de espaços de poder e distâncias sociais, mas também é destacado como uma maneira cordial de driblar leis e normas (VIEIRA; COSTA; BARBOSA, 1982), tanto legais, como sociais, sendo justificado, conscientemente ou inconscientemente, por diversos motivos. Entre eles, destacam-se desconfiança nas regras (DAMATTA, 1989), recurso de poder (GAGLIETTI, 2006; VIEIRA; COSTA; BARBOSA, 1982), justiça (BRAGA; BEZERRA, 2017), controle social e competição (MOTTA; ALCADIPANI, 1999). 
A malandragem, do ponto de vista social, é como um caminho entre o lícito e o ilícito (CRISTINO, 2009; ROCHA, 2006), e um de estilo de vida originalmente brasileiro, surgindo como uma promessa de inversão e relativização da ordem social (DAMATTA, 1983). Em conjunto com a passagem do tempo, a malandragem vai convergindo com o 'jeitinho brasileiro', como um conjunto de atitudes mais domesticadas e purificadas, distanciando-se das representações marginais, violentas e perigosas (ROCHA, 2006).

O jeitinho e a malandragem, de maneira sinônima ou não, são percebidos como uma maneira especial, eficiente, rápida e criativa de agir em prol de controlar, contornar, facilitar e resolver situações (VIEIRA; COSTA; BARBOSA, 1982). As várias vertentes do 'jeitinho' indicam que essa característica não é uma categoria de contornos rígidos. O que é, ou não é jeitinho, variam bastante, oscilando de uma ideia negativa a uma ideia positiva. Positivamente, o jeitinho é um modelo de 'favor', que evidencia o lado cordial, caloroso, simpático, esperto, além de virar um elemento que humaniza relações (LOURENÇO, 2014). Negativamente, é associado à ideia de tirar vantagem de uma situação, em diversos casos em desfavor a terceiros (DAMATTA, 1986).

Tanto Vieira, Costa e Barbosa (1982), como DaMatta (1989), percebem a questão do jeitinho pela ótica da formalidade. O formalismo seria a distinção entre regras prescritas legalmente e as reais atitudes praticadas a partir de sua implementação, ou seja, o comportamento efetivo dos indivíduos (VIEIRA; COSTA; BARBOSA, 1982), sendo o jeitinho uma característica de pouca formalidade. Entretanto, o fato de o 'jeitinho' proporcionar a determinados indivíduos possibilidade de burlar regras faz com que todos que não se beneficiam dessa exceção questionem a validade das mesmas, mas, no entanto, utilizem desse recurso para diminuir disparidades cotidianas. Acaba ocorrendo, então, uma desmoralização das regras, gerando assim um ciclo de desconfiança, e um ciclo de 'jeitinhos'. Essa descrença é tratada de forma natural, já que ocorre uma despreocupação com as leis e ao cumprimento delas, mas os 'problemas' são resolvidos de forma satisfatória (DAMATTA, 1989; PRADO, 2016).

A relação entre poder e 'jeitinho' também é estudada no campo social (DAMATTA, 1989; FLACH, 2012; GAGLIETTI, 2006; PRADO, 2016; VIEIRA; COSTA; BARBOSA, 1982). A famosa frase "Você sabe com quem está falando?", discutida por Barbosa (1992), expõe a falta de limites por meio da hierarquização, e evidencia relações de poder na sociedade, sendo considerada um dos inícios do ‘jeitinho', porém de forma menos amigável e positiva do que é feito normalmente. Além disso, a pessoa que concede o 'jeitinho' tem seu 
poder fortalecido no momento que passa de cumpridor da lei para um aferidor de sua pertinência e aplicação (MOTTA; ALCADIPANI, 1999).

Em defesa do 'jeitinho', Motta e Alcapadiani (1999) explicam que esse ato se diferencia da corrupção visto que ele não é incentivado originalmente por ganho monetário, já que a pessoa que dá o 'jeitinho' não recebe ganho material ao concedê-lo (ALMEIDA, 2015; DAMATTA, 1989; LAMEIRA; BERTRAND, 2008). A partir disso, defende-se o 'jeitinho' como forma de controle social e competição, mas também como uma forma de fazer frente a todas as possíveis eventualidades (LOURENÇO, 2014). Quem pede o 'jeitinho' e quem o executa compete com o Estado por meio de uma característica cultural. Trata-se de um mecanismo social pelo qual solicitantes e executores do jeitinho competem entre si pelo poder, as relações sociais que colocam em jogo para atingir seus objetivos e a aferição do que é justo ou não, refletindo ainda mais a sociedade relacional (MOTTA; ALCADIPANI, 1999).

Chauvel (2000) percebeu como indivíduos de baixa renda se preocupavam em serem vistos como 'malandros' quando queriam fazer uma reclamação legítima a empresas. Esses consumidores se preocupavam com a forma como as queixas poderiam ser interpretadas como uma forma de 'tirar vantagem'. Mesmo nos dias atuais, esses consumidores ainda se preocupam com a percepção de outros sobre a sua honestidade e dignidade (HEMAIS; CASOTTI, 2017). No entanto, preferem resolver seus problemas de formas mais simples, contando com a 'camaradagem' do vendedor, 'explicando o que ocorreu, para conseguir uma solução' e 'tentando dar um jeito', o que pode ser entendido também como uma forma de aplicar o 'jeitinho'. Pensam dessa forma pois acreditam que seria a maneira mais fácil, rápida, prática e justa de conseguir resolver o que desejam (HEMAIS; CASOTTI, 2017; MELO; VALE; CORRÊA, 2018), visto que o aspecto relacional entre empresa e consumidor não é amistoso, porém, com os vendedores haveria chance de ser.

A religião também se coloca como relevante nas características culturais brasileiras, visto que acaba pautando normas, ideologias, éticas e condutas (SANCHIS, 2008), exercendo, assim, influência sobre todos os outros espaços da sociedade. Em ressonância com o jeitinho, a religião também é uma forma de aproximar pessoas e classes, sendo, então, uma forma de permitir uma relação globalizada não somente com os deuses, mas também com a população ao redor. Por outro lado, a religião também consegue 'explicar' relações duais de poder, como as que ocorrem entre ricos e pobres, por exemplo (DAMATTA, 1989; PIERUCCI, 2006). Com isso, pode-se também considerar que apesar do que foi retratado anteriormente, a 
religião implica em uma forma de reacreditar, tanto nas coisas do mundo, como nas relações entre pessoas e atitudes cotidianas (DAMATTA, 1989).

\section{PROCEDIMENTOS METODOLÓGICOS}

Em vista do pouco conhecimento na literatura de marketing sobre o tema aqui abordado (HUANG; MIAO, 2013; ROSENBAUM; KUNTZE; WOOLDRIDGE, 2011), será conduzida uma pesquisa exploratória. Esse tipo de pesquisa tem como finalidade a formação de ideias para um entendimento do conjunto do problema, a fim de auxiliar a investigação e verificação de comportamentos humanos (RÉVILLION, 2003). A pesquisa também se caracteriza por ser de cunho qualitativo, pois permite realçar o caráter subjetivo do entendimento acerca do tema do presente estudo, focando em dados que emergem do cotidiano e podem interpretar com eficiência a complexidade de uma situação (CAHILL, 1996).

Optou-se, também, por utilizar a técnica projetiva na coleta de dados, por essa permitir indagar aos entrevistados sobre determinadas situações de forma indireta, possibilitando que se sintam mais tranquilos e seguros em responderem o que realmente acreditam. Isso ocorre porque os entrevistados analisam a atitude de um indivíduo, e não a dele próprio, posto que é 'projetada' a situação vivida por um personagem (WILL; EADIE; MACASKILL, 1996). No presente estudo, escolheu-se essa técnica por acreditar que consumidores se sentiriam constrangidos em falar claramente sobre seus comportamentos de reclamações fraudulentas.

Foram realizadas 27 entrevistas com consumidores acessados por conveniência. Desse total, 12 entrevistados eram homens e 15 eram mulheres, com idades entre 24 e 79 anos, e moradores do Estado do Rio de Janeiro. Entre eles, havia servidor público, publicitário, empresário, assistente social, faxineiro, recepcionista, massoterapeuta, entre outras profissões. Não houve uma restrição para a participação dos entrevistados em torno de um comportamento padrão ou elemento comum, a não ser serem brasileiros. A intenção, dessa forma, foi obter um quadro mais abrangente de perfis.

A coleta de dados foi realizada a partir de três formulários, cada qual com duas situações que reflitam as seis motivações para reclamações fraudulentas identificadas por Reynolds \& Harris (2005) - Freeloaders, Fraudulent Returners, Fault Transferers, Solitary Ego Gain, Peer-Induced Esteem Seekers e Disruptive Gains. Os formulários possuíam duas motivações cada, a fim de tornar as entrevistas mais dinâmicas e menos cansativas. As 
perguntas realizadas questionavam a opinião dos entrevistados acerca das situações descritas, se eles concordavam ou não com o ocorrido, e depois exploravam a relação entre essas situações com a cultura brasileira.

Os formulários também se diferenciavam para o público feminino e o masculino, pois os personagens hipotéticos eram tanto homens, quanto mulheres, o que facilitaria a projeção dos entrevistados à situação apresentada (WILL; EADIE; MACASKILL, 1996). As situações retratadas nos formulários eram as mesmas, sendo alterados apenas o nome dos protagonistas de cada situação, em função do gênero do respondente. De forma a deixar mais claro como isso ocorreu, serão demonstradas a seguir duas situações descritas nos formulários, que retratam a motivação classificada por Reynolds e Harris (2005) de Freeloaders:

- Maria ia receber alguns amigos em casa e precisava de um aparelho de DVD novo para entretê-los. Ela costumava comprar tais produtos em uma loja que ficava em outro estado, mas que oferecia serviço de entrega. Seus amigos chegariam em três semanas, e o prazo de entrega que a loja dava era de uma semana, e que, se o produto não chegasse, o consumidor seria reembolsado pelo valor da compra. Maria sabia que dificilmente a loja conseguiria entregar o produto dentro do prazo porque, além da loja ser em outro estado, o endereço de sua residência era confuso, podendo gerar ainda mais atraso. De qualquer forma, ela comprou o aparelho. Quando passou do dia de entrega do produto, ela ligou para a loja reclamando e dizendo que era um absurdo a falta de comprimento do prometido. A loja prontamente devolveu o valor do aparelho, seguindo a sua política. Poucos dias depois, o produto chegou à casa de Maria. No fim, ela acabou ficando com o aparelho, que saiu de graça, e conseguiu usá-lo enquanto os seus amigos o visitavam.

- Hélio ia receber alguns amigos em casa e precisava de um aparelho de DVD novo para entretê-los. Ele costumava comprar tais produtos em uma loja que ficava em outro estado, mas que oferecia serviço de entrega. Seus amigos chegariam em três semanas, e o prazo de entrega que a loja dava era de uma semana, e que, se o produto não chegasse, o consumidor seria reembolsado pelo valor da compra. Hélio sabia que dificilmente a loja conseguiria entregar o produto dentro do prazo porque, além da loja ser em outro estado, o endereço de sua residência era confuso, podendo gerar ainda mais atraso. De qualquer forma, ele comprou o aparelho. Quando passou do dia de entrega do produto, ele ligou para a loja reclamando e dizendo que era um absurdo a falta de comprimento do prometido. A loja prontamente devolveu o valor do aparelho, seguindo a sua política. Poucos dias depois, o 
produto chegou à casa de Hélio. No fim, ele acabou ficando com o aparelho, que saiu de graça, e conseguiu usá-lo enquanto os seus amigos o visitavam.

As demais situações exibidas aos entrevistados são ilustradas a seguir. Os nomes masculinos e femininos dos personagens hipotéticos são descritos juntos para finalidades ilustrativas da situação:

- $\quad$ Solitary Ego Gain: Luiz/Luiza é engenheiro(a) de uma das melhores empresas do Rio de Janeiro. Ele/ela já possui um carro, mas decidiu comprar um novo. Para esse novo carro, ele/ela escolheu um que tinha o interior bege. Porém, no dia quando foi buscar o automóvel, percebeu que o interior não estava no tom de bege que ele/ela gostaria. Luiz/Luiza, então, entendendo o ocorrido, foi em direção ao vendedor e fez o seguinte discurso: "É um absurdo a falta de atenção dessa concessionária. Sou uma pessoa extremamente importante e meu carro não está como eu pedi. Não vou andar com um carro desse jeito. Como vocês fazem uma coisa dessas?! Vou falar mal desse lugar para todos na empresa que eu trabalho! Vou avisar que são extremamente desatentos e não fazem o que foi solicitado!"

- $\quad$ Disruptive Gains: Mariana/Mariano teve um problema no passado com uma marca de aparelhos celular que só foi resolvido na justiça, após muito desgaste. Mariana/Mariano ficou tão estressada(o), na época, que chegou a ter problemas de pele. No fim, ela/ele ganhou o processo, mas não ficou satisfeita(o). Um ano depois, Mariana/Mariano encomendou um novo aparelho celular dessa mesma marca. $\mathrm{O}$ produto funcionava perfeitamente, e atendia todas as especificações descritas, mas, como vingança, ela/ele ligou para a empresa para reclamar, alegando que o produto não funcionava como estava prometido e que, por isso, queria seu dinheiro de volta e vários outros benefícios de graça ou iria falar sobre o problema em suas redes sociais e em sites de reclamação na Internet.

- $\quad$ Fault Transferers: Leticia/Mauro comprou um micro-ondas e pediu que fosse entregue na sua casa. Assim que o micro-ondas chegou, ela/ele o retirou da caixa, e deixou o produto apoiado no chão, para ir beber uma água. Quando voltou, acabou tropeçando e molhou o micro-ondas inteiro, comprometendo seu funcionamento. Quando percebeu que o aparelho não ligava, Leticia/Mauro ficou nervosa(o), pois havia gastado muito dinheiro na compra do produto. Ao mesmo tempo, ficou com raiva e ligou para a empresa reclamando que o produto que eles enviaram não estava funcionando. Afinal, pensou: "o que é um microondas para essa empresa que vende tantos?" 
- Peer-Induced Esteem Seekers: Felipe/Amanda está namorando há poucos meses Aline/Francisco. Um dia, Felipe/Amanda comprou umas cadeiras para a sua casa, mas decidiu trocá-la e foi com Aline/Francisco à loja. Logo na primeira cadeira que o vendedor trouxe, ele/ela já tinha gostado, porém, na intenção de chamar atenção de Aline, ele começou a fazer vários pedidos ao vendedor, e ficou falando que as opções que ele estava trazendo não combinavam com o estilo que ele havia pedido. Ao final, Felipe disse que ficaria com a primeira cadeira que ele havia mostrado, pois era a opção menos pior.

- $\quad$ Fraudulent Returners: Juliana/Juliano comprou um sapato caro em uma loja famosa para usar no jantar de lançamento da empresa de sua irmã. Ela/ele sabia que não iria conseguir ir a nenhum outro evento com esse sapato, então, tomou muito cuidado para não o danificar. No dia seguinte ao jantar, Juliana/Juliano foi à loja, disse que não havia gostado do sapato e pediu para devolvê-lo, recebendo o reembolso total do valor.

Os produtos utilizados nas situações descritas acima foram escolhidos a partir do ranking divulgado no Boletim Sindec (2017), que indica quais foram os principais assuntos reclamados por consumidores aos Procons espalhados pelo Brasil no ano de 2017. O presente trabalho optou apenas por utilizar produtos nas situações apresentados aos entrevistados, e não serviços, dados os elementos intangíveis dos segundos. Assim, seria mais fácil minimizar possíveis dúvidas dos entrevistados durante a entrevista. Escolheu-se, portanto, os seis primeiros produtos com o maior número de reclamações aos Procons, sendo eles: aparelho celular, móveis, eletrodomésticos de linha branca, vestuário, carros, e televisão/aparelho DVD/filmadora.

Como preparação para as entrevistas, foram realizadas duas baterias de pré-teste com quatro consumidores, a fim de apurar se a coleta de informações estava sendo feita de forma adequada e atendendo às expectativas do trabalho (GUMMESSON, 2005). Na primeira bateria, foram identificadas falhas nas descrições das situações e nas perguntas, deixando os entrevistados confusos, e influenciando algumas respostas. A partir disso, foram feitos os ajustes necessários e, em seguida, realizada a segunda bateria com mais dois entrevistados. Não havendo mais problemas de entendimento, seguiu-se com a coleta de dados.

As entrevistas foram realizadas presencialmente, e em um local de preferência dos entrevistados, de forma a fazer com que se sentissem confortáveis. As entrevistas foram gravadas com o consentimento dos entrevistados, para depois serem transcritas.

Após a transcrição das entrevistas, a análise dos dados ocorreu em duas etapas. Em um primeiro momento, os dados foram codificados utilizando o programa Atlas-ti. Os códigos 
foram criados levando-se em consideração o referencial teórico e temas que surgiram durante as entrevistas (RUBIN; RUBIN, 2005). A partir desse processo, foram cadastrados 67 códigos, que ajudaram a chegar a uma saturação dos dados, que ocorreu quando novos códigos não mais surgiam à medida que cada transcrição de entrevista era codificada (GUEST; BUNCE; JOHNSON, 2006). Em um segundo momento de análise, os códigos foram agrupados, a fim de se encontrar semelhanças e diferenças nos relatos dos entrevistados (GUMMESSON, 2005). Dessa forma, foi possível chegar às categorias de análise do estudo, discutidas a seguir.

\section{ANÁLISE DOS RESULTADOS}

A partir da análise dos dados, foi possível perceber que características da cultura brasileira aparecem nos discursos dos entrevistados sobre as reclamações fraudulentas de três principais formas. O primeiro item discute aspectos que associam 'casa' e 'rua' a reclamações fraudulentas. Em seguida, é apresentada a relação informal entre o 'jeitinho brasileiro' e a 'malandragem' a tais reclamações. O terceiro, por fim, debate a visão dos entrevistados sobre a influência da religião sobre reclamações fraudulentas.

É importante destacar que, devido ao uso da técnica projetiva, a perspectiva de DaMatta (1986) sobre a cultura brasileira e sua ideia de sociedade relacional se fez relevante para o estudo. Foi possível perceber que, mesmo sem conhecer os personagens dos casos apresentados, os entrevistados criaram uma relação com esses a partir das histórias contadas e das motivações por trás de cada um deles - achado esse também encontrado em Hemais e Casotti (2014). Com isso, além da relação entre a empresa e os seus funcionários e os entrevistados, os participantes da pesquisa também respondiam determinadas perguntas como se tivesse uma relação com o próprio consumidor hipotético, colocando-se, em alguns momentos, em seu lugar ou imaginando que poderiam ser pessoas próximas a eles. A seguir, essa discussão é apresentada em maior detalhes dentro das três categorias de análise do estudo.

\section{1 'CASA' E 'RUA' E SUAS RELAÇÕES COM RECLAMAÇÕES FRAUDULENTAS}

Ao discutir suas opiniões sobre reclamações fraudulentas, os entrevistados relatavam justificativas para concordar com ou rejeitar a queixa do consumidor hipotético que se 
relacionavam com aspectos de 'casa' e 'rua', conforme descritos por DaMatta (1989). Enquanto que a 'casa' pode ser entendida como um espaço no qual as pessoas que fazem parte desse fórum devem ser defendidas e seu valores respeitados, a 'rua' é tida como envolta de desconfiança e insegurança, um local onde batalhas são travadas e vidas são moldadas de forma mais bruta. No entanto, a ideia de se sentir em 'casa', mas estando na 'rua', é uma característica relevante da cultura brasileira, pois traz uma cordialidade e uma sensação de entendimento com outros indivíduos a partir do aspecto relacional (DAMATTA, 1989).

Em uma situação de reclamação "normal" entre um consumidor e uma empresa, na qual o primeiro legitimamente se queixa de um problema causado pela segunda, os entrevistados entendem que há uma relação de 'rua' entre as partes, dado que o consumidor se expõe à desconfiança da empresa em seu pleito, o que o levaria a precisar "brigar para conseguir" aquilo que acredita ser seu por direito (CHAUVEL, 2000). Todavia, quando o elemento da fraude é adicionado à reclamação, os entrevistados relatam aspectos relacionados à 'casa', pois se colocam em uma posição de defender aqueles que poderiam ser prejudicados pelas ações do consumidor hipotético.

Cabe destacar, entretanto, que essa interpretação dos entrevistados não deve ser tratada de maneira dualista (como se fosse algo bom ou ruim). Comumente, suas percepções associadas a 'casa' englobavam noções daquilo caracterizado como 'rua', e vice-versa. Afinal, o próprio DaMatta (1986) discute tais conceitos mostrando seus contrastes e suas proximidades. Se, por um lado, é na 'rua' que se busca melhoras da 'casa', por outro, o que é feito na 'rua' não necessariamente é aceito em 'casa'. Assim, a 'casa' e a 'rua' são irmãs, pois pertencem a uma mesma instituição social, enviesadas somente por escolhas de visões pessoais, diferenciando ou complementando a experiência social brasileira (DAMATTA, 2000). A lógica de 'rua' aparece nos relatos de alguns entrevistados no momento que concordam com a reclamação fraudulenta dos consumidores hipotéticos, principalmente quando o produto comprado é de natureza mais cara e demandante de mais tempo para a tomada de decisão sobre a sua compra. Isso pode ser visto, por exemplo, quando o Entrevistado 21, ao responder sobre a situação relacionada à motivação do tipo Solitary Ego Gain, diz que: "Se fosse comigo, eu voltaria lá (na loja onde comprou o carro). Claro! Porque eu 'tô' comprando um carro, que é uma coisa cara". A Entrevistada 11 também segue essa linha de pensamento ao relatar que concorda com a atitude da consumidora hipotética da situação associada à motivação do tipo Peer-Induced Esteem Seekers: “....Se ela é uma pessoa que às vezes precisa ver outras opções antes de ter certeza do que ela realmente quer, acho 
que é válido". Em ambos os casos, percebe-se que os entrevistados estão preocupados em garantir que os seus direitos sejam respeitados (DAMATTA, 1989), mesmo que isso signifique se indispor com a empresa ou os vendedores por uma questão de vaidade própria ou relacionada a terceiros (REYNOLDS; HARRIS, 2005).

A caracterização da relação entre consumidor hipotético e empresa como uma de 'rua' também se fez evidente quando alguns entrevistados foram apresentados à situação associada à motivação do tipo Freeloaders: "A loja falava que entregava em uma semana. A loja também 'tá errada de prometer uma coisa e não cumprir" (Entrevistado 20). Sua justificativa se baseia na ideia de que a empresa possui uma "política de devolução clara" e que o consumidor poderia, portanto, fazer uso dela para conseguir uma compensação, já que não obteve o produto dentro do prazo prometido. Há uma preocupação desses entrevistados em garantir que o combinado entre as partes seja cumprido e a ordem prevaleça (DAMATTA, 1989). Para eles, a partir do momento que o consumidor deseja comprar de uma empresa, precisa aceitar as regras que lhe são apresentadas para tal. Na situação hipotética, o consumidor, portanto, aparenta cumprir o seu papel - mesmo que tenha segundas intenções quando o faz -, mas a empresa não. Há uma "quebra das regras", então, e a parte que não as cumpriu precisa retratar a outra, a fim de evitar maiores desgastes entre ambos.

Os relatos que relacionam as reclamações fraudulentas a algo de 'rua' foram substituídos por outros, mais próximos à conceituação de 'casa', quando outros entrevistados percebiam que as ações do consumidor hipotético poderiam resultar em perdas para a empresa, os seus funcionários, os outros consumidores que também poderiam ser lesados pela situação oportunista e, até, o próprio consumidor hipotético, como se todos fizessem parte de seu círculo de confiança e, portanto, passível de sua defesa (DAMATTA, 1989). Os entrevistados, portanto, parecem ter criado uma relação com alguns dos personagens fictícios apresentados a eles, trazendo um cuidado de 'casa' a elementos normalmente associados a 'rua', mesmo que não pertencessem ao seu ciclo considerado parental.

Tal inclinação dos entrevistados em defender a parte prejudicada foi vista primeiramente quando alguns participantes da pesquisa entendiam que a reclamação era feita com o objetivo de o consumidor hipotético "se dar bem pelas costas da empresa". Haveria, portanto, elementos de "má-fe"” e "jogo sujo" por parte do reclamante, e que esse comportamento geraria perdas para a empresa - caracterizada como tendo feito "nada de errado" -, que sairia "em desvantagem". Esses entrevistados entendem que a reclamação foi planejada de forma premeditada pelo consumidor hipotético, que desde o início tinha 
distorções quanto às suas intenções. O fato de o reclamante usar de artifícios fraudulentos para obter um ganho em cima da empresa, portanto, é um desrespeito às regras que ambas as partes concordam ao se engajar em uma troca comercial, e, por isso, condenável. A empresa, nesse caso, foi correta em sua conduta, não podendo ser, consequentemente, prejudicada. Os relatos demonstram haver uma preocupação entre os entrevistados em garantir que "a reputação" da empresa não seja colocada em discussão, pois a reclamação "foi, de fato, fraudulenta".

Diferentemente do grupo que relatou concordar com a reclamação fraudulenta associada à motivação do tipo Freeloaders, esse grupo de entrevistados se coloca ao lado da empresa, condenando o consumidor hipotético. Para eles, não há justificativa para o comportamento adotado, ainda mais se esse for prejudicial a terceiros. Conforme DaMatta (2000) explica, 'casa' e 'rua' são conceitos irmãos, complementares, pois pertencem à mesma instituição social. A escolha por adotar um ou outro é sutil, e ocorre a partir da relação que o entrevistado escolhe ter com os personagens fictícios.

Além da empresa, os entrevistados também demonstram preocupações com as consequências que as reclamações fraudulentas poderiam trazer para os funcionários da empresa. Novamente, aqui, elementos de 'casa' se misturam com os de 'rua', quando se percebe uma relação entre entrevistados e funcionários, na qual os primeiros agem com preocupação sobre os segundos, como se fossem próximos. Seus relatos mostram inquietações com o futuro profissional desses empregados, que poderiam ser repreendidos por seus chefes ou, até, "perder seu emprego" por "cair na conversa" do consumidor hipotético. Em geral, o que catalisava tais pensamentos era a discordância com a forma como o consumidor hipotético supostamente se dirigia ao funcionário que o atendia na situação apresentada aos entrevistados, sendo considerada "exagerada" e "desnecessária", como ilustra o Entrevistado 20 quando discute o caso associado à motivação de Solitary Ego Gain: "Mas de jeito nenhum eu chegaria grosso assim. Falaria assim: 'olha só, vocês vieram com a cor errada, eu queria que trocasse, porque eu pedi bege'. Enfim, nada de fazer escândalo...”. Os entrevistados também ressaltaram que tal ato pode atrapalhar o funcionário, que precisaria gastar mais tempo e energia em seu atendimento, porém sem que isso lhe trouxesse benefícios, conforme relata a Entrevistada 2 ao responder sobre o caso da motivação do tipo Peer-Induced Esteem Seekers: “...ela (consumidora hipotética) sacaneou o empregado. O empregado ficou escolhendo uma porção de coisa, mostrando uma porção de coisa. Ocupou o tempo dela e do empregado à toa, numa coisa que ela podia ter sido muito mais prática”. 
O fato de os entrevistados darem grande atenção à forma como a reclamação foi feita parece prevalecer sob o problema de a queixa realizada ao funcionário ser de natureza fraudulenta (KHANTIMIROV, 2018). O comportamento adotado pelo consumidor hipotético é, então, condenado pelos entrevistados até mais do que a queixa em si, pois não propõe a empatia de se colocar no lugar do outro, e a proteção com o lado menos favorecido de todo o contexto. Isso pode ser entendido como uma falta de consciência social coletiva e falta de um alinhamento moral com o consumidor hipotético, sendo características comumente associadas ao conceito de 'casa', embora a situação descrita se caracterize como sendo uma de 'rua' (DAMATTA, 1989).

Os entrevistados também demonstraram preocupações com outros consumidores que poderiam ser afetados pelo ato da reclamação fraudulenta, mas que nada tinha a ver com a situação hipotética. Imagina-se que isso ocorra dada a ideia de 'casa' ser um espaço no qual se busca a proteção dos membros mais frágeis, respeitando, assim, sua 'honra' (DAMATTA, 1989). Os entrevistados, portanto, parecem encontrar na 'rua' a 'casa', quando são solidários ao coletivo, mesmo sendo um ambiente onde ele geralmente é indivíduo (DAMATTA, 2000). Isso ocorreu especialmente quando os entrevistados relatavam suas opiniões a respeito do caso associado à motivação do tipo Fraudulent Returners. Os participantes da pesquisa entendiam que a devolução dos sapatos por parte do consumidor hipotético seria problemática, pois a empresa colocaria o produto para vender novamente, como se não tivesse sido utilizado anteriormente. Outro consumidor, portanto, seria prejudicado, visto que pagaria um preço pelo produto como se esse fosse novo, o que, de fato, não é verdade, caracterizando uma situação "injusta", e "moralmente errada", conforme o Entrevistado 11 relata: "Errado, né? Porque ele usou o sapato e depois pediu o dinheiro de volta. Quem for usar esse sapato já não vai ser um sapato novo, né? Vai ser um sapato usado".

O próprio consumidor hipotético também foi objeto de defesa dos entrevistados, especialmente quando discutiam a situação relacionada à motivação do tipo Fault Transferers. Os participantes da pesquisa entenderam que a reclamação fraudulenta foi equivocada, mas foram mais amenos ao falar sobre a ação do consumidor. Essa atitude é típica do caráter conciliatório do brasileiro, que se expressa quando ele encontra na 'rua' a 'casa' (DAMATTA, 2000). Apesar de haver "desonestidade" no caso, foi possível perceber também certa sensibilização com a situação em razão da perda monetária e da quebra do produto, conforme explica a Entrevistada 2: "Essa situação é meia complicada, né? Porque ela (consumidor hipotética) também não queria perder o dinheiro, coitada. Mas, também a 
empresa não teve culpa, a culpa foi dela... eu acho que não é certa a maneira dela agir, mas cada um tem a sua opção, cada um tem o seu jeito de pensar." Parece haver entre os entrevistados certa "pena" em relação ao consumidor hipotético, um "compadecimento", pois não foi vista uma premeditação nas ações do mesmo. No fim, o consumidor ficaria em "desvantagem" na situação, pois supostamente "não teria dinheiro" para comprar um segundo micro-ondas para substituir aquele quebrado. Na constituição daquilo que compõe a 'casa' desses entrevistados, isso remeteria a uma situação vexatória ao consumidor, que não mereceria tanto.

Além das discussões sobre 'casa' e 'rua', os entrevistados também associaram as reclamações fraudulentas a outras características culturais do Brasil, especialmente no que diz respeito ao 'jeitinho brasileiro' e a 'malandragem'. O item a seguir, portanto, discute tais associações.

\subsection{JEITINHO BRASILEIRO E MALANDRAGEM RELACIONADOS A RECLAMAÇÕES FRAUDULENTAS}

Entre os entrevistados que viam a reclamação fraudulenta como "algo errado" e envolta de "má-fé", sua justificativa se baseava no pensamento de que se tratava de uma forma de "tirar vantagem" da situação, ou seja, que o consumidor hipotético estava tentando fazer uso do 'jeitinho brasileiro' e da 'malandragem' para obter vantagens. Embora o ‘jeitinho' seja discutido pela literatura como tendo virtudes positivas, pois seria uma postura criativa adotada por brasileiros para resolverem problemas, sem que necessariamente isso trouxesse implicações negativas a terceiros (VIEIRA; COSTA; BARBOSA, 1982), não foi dessa forma como esse grupo de entrevistados o interpretou. Nos casos apresentados a seguir, houve a prevalência do polo negativo do 'jeitinho'. Para os entrevistados, o 'jeitinho', nas situações relatadas, caminhou junto com a 'malandragem' e ambos giram em torno das ideias de "desonestidade" e "esperteza" (BEMFICA, 2015; BRAGA; BEZERRA, 2017; FLACH, 2012), como pode ser visto pelo relato do entrevistado 6: "Infelizmente, a gente vê que sempre procuram dar um jeitinho pra tudo, né? E, às vezes, esse jeitinho ultrapassa, não é a coisa honesta".

Essa percepção negativa dos entrevistados ocorreu, por exemplo, quando entendiam que o consumidor hipotético estaria ameaçando a empresa em sua busca de vingança contra 
a mesma, associada especialmente ao caso relacionado à motivação do tipo Disruptive Gains, conforme os relatos a seguir ilustram:

Por ele (consumidor hipotético) entrar num conflito não amistoso, já tinha perdido a discussão antes mesmo dela começar. E, aí, depois, tentar se aproveitar, é algo bem pobre, né? É uma coisa que a maioria até tenta, né? Tirar vantagem, esse jeitinho brasileiro aí. Mas, pra mim, é falta de caráter (Entrevistado 4).

Ele (o consumidor hipotético) teve a regalia de ser indenizado... aí, compra outro [aparelho celular] e alega isso [que o produto não funcionava como estava prometido e que, por isso, queria seu dinheiro de volta e vários outros benefícios de graça ou iria falar sobre o problema em suas redes sociais e em sites de reclamação na Internet]?! (Entrevistado 9).

Para os entrevistados, o fato de o consumidor hipotético ter maquinado uma situação inexistente de insatisfação e, ainda, ter ameaçado falar mal da empresa em suas redes sociais e em sites de reclamação virtuais fez com que esse indivíduo tenha buscado, por meio de alegações de poder (GAGLIETTI, 2006; PRADO, 2016), um 'jeitinho’ para obter ganhos indevidos e ameaçar a empresa. Há, portanto, uma tentativa de tirar proveito da situação através de desvios a uma conduta considerada correta por parte dos entrevistados. Tal visão aponta para a hierarquização social existente no Brasil, por meio da qual determinadas pessoas conseguem melhores condições do que outras porque possuem acesso a recursos que lhes proferem mais poder (BARBOSA, 1992); no caso, a possibilidade de manchar a imagem da empresa por possuir acesso a diversos outros consumidores conectados à Internet. Segundo um entrevistado, é por causa de tais privilégios que "o Brasil não anda", sendo necessário, então, ir contra tais comportamentos.

Outro fator que fez os entrevistados associarem a reclamação fraudulenta ao 'jeitinho' e a 'malandragem' foi sua visão de que tal comportamento fora adotado como uma forma de o consumidor hipotético obter status e afirmação social (PIRON; YOUNG, 2000). Essa perspectiva difere da discutida anteriormente sobre poder pois enquanto que, na primeira, havia um desejo do consumidor hipotético de vingança, nesse caso a reclamação à empresa parece ser somente um trampolim para uma diferenciação entre pares, sem que necessariamente haja uma intenção premeditada de trazer danos a terceiros (VIEIRA; COSTA; BARBOSA, 1982). O relato do Entrevistado 13, ao falar sobre o caso relacionado à motivação do tipo Fraudulent Returners, ajuda a ilustrar tal análise: "Eu acho que as pessoas são muito ligadas à marca. Eu nunca fui ligado à marca. Eu sempre fui ligado à roupa que eu 
gosto, que me vista bem... eu jamais vou comprar uma roupa que eu vá usar uma única vez na minha vida".

A reclamação fraudulenta, nesse caso, é vista pelos entrevistados, portanto, como uma forma de o consumidor hipotético diminuir disparidades cotidianas que vivencia (DAMATTA, 1989). O fato de esse indivíduo ter buscado um sapato caro, de uma marca conhecida, para utilizá-lo em somente um evento, e depois devolvê-lo, obtendo o reembolso total pelo mesmo, indica aos entrevistados que o personagem "acha que está abaixo dos outros" e, por isso, precisaria aparentar pertencer ao mundo daqueles acima dele para fazer parte do mesmo. A ideia de que é usado um ‘jeitinho' para resolver essa disparidade seria, então, uma forma de contornar as diferenças sociais existentes na sociedade brasileira (PRADO, 2016).

Neste caso, por mais que os entrevistados entendam que o consumidor hipotético 'não deveria ter feito isso', há um entendimento de que não 'havia necessidade disso'. A situação poderia ser evitada se o consumidor não precisasse se autoafirmar com um vestuário de marca para estar 'bem vestido', ou provar algum valor associado a marcas caras, ressaltando a característica relacional da cultura brasileira. Mesmo tendo adotado uma postura considerada errada, há uma preocupação com as escolhas desse consumidor hipotético. Tanto que, nesse caso, os entrevistados julgam o consumidor hipotético de forma mais branda.

Esses entrevistados ainda percebem que o consumidor hipotético agiu de "forma malandra" e "quis se dar bem na situação" ao interpretarem as ações que precedem a reclamação fraudulenta como irresponsáveis, especialmente ao falar do caso associado à motivação do tipo Fault Transferers. Segundo o Entrevistado 3, o reclamante está: "Errado. Ah, azar. Ele fez besteira, por preguiça... se ele quebrou o aparelho, não tem por que ele reclamar. Ele tem que aceitar isso e buscar a melhor forma de comprar outro".

Para os participantes da pesquisa, a 'malandragem' adotada na situação beira a ilicitude (ROCHA, 2006), pois o consumidor hipotético sabe que a culpa pelo problema é dele, mas mesmo assim busca fugir de sua responsabilidade. Há, de certa forma, uma relativização da ordem social (DAMATTA, 1983), dado que os papéis atribuídos às partes deixam de ser claros a partir do momento que o reclamante rompe com as suas atribuições e coloca em xeque aquelas relativas a terceiros. Em razão disso, alguns entrevistados alegam que empresas devem se precaver contra esse tipo de situação, conforme ilustra o relato do entrevistado 1: "Por isso, hoje, muitas empresas até tiram foto, mostram evidencias que o produto 'tá funcionando, pra se certificar que situações assim não vão acontecer novamente". 
Os entrevistados entendem que o 'jeitinho' e a 'malandragem' são partes intrínsecas da cultura dos brasileiros, mas percebem que ambos esses comportamentos estão subordinados a uma ordem maior, relacionada à religião, que limita o quanto as pessoas adotam tais posturas tidas como negativas. O próximo item discute, então, essa questão.

\subsection{RELIGIÃO COMO LIMITADORA DE RECLAMAÇÕES FRAUDULENTAS}

Durante as entrevistas, foi observado que um grupo de entrevistados mencionou a religião, de forma direta e indireta, ao serem questionados sobre o comportamento dos consumidores hipotéticos, principalmente na hora em que deveriam indicar se concordavam ou discordavam com a reclamação fraudulenta. Esse encadeamento entre o 'errado' e a religião sugere uma ligação com mais profundidade entre esses dois conceitos.

A religião também foi referenciada nesse caso como forma de não se eximir de responsabilidades. Para esses entrevistados, uma força superior estaria "de olho" em tais atos ilícitos, gerando sentimentos de preocupação e apreensão entre os entrevistados em não cometerem fraudes dessa natureza, como pode ser observado pelo trecho do entrevistado 7 : “... nós temos, assim, um histórico muito grande das pessoas não quererem assumir uma responsabilidade que é sua, né?... Eu vejo muito essa questão da formação religiosa das pessoas, essa questão de culpa".

Essa visão dos entrevistados pode ser entendida pelo fato de que a religião sempre foi relevante na constituição da cultura brasileira, e a partir dela foram criadas relações não somente com deuses, mas também entre homens e seres vivos que formam a sociedade (DAMATTA, 1989). Em razão disso, a religião norteia condutas do dia a dia, pautando éticas morais cotidianas e construindo ideologias (DAMATTA, 2000), o que explica o motivo de ações antiéticas, oportunistas e fraudulentas serem condenadas por esse grupo de entrevistados.

Alguns entrevistados entenderam que a noção de que estaria fazendo mal a um terceiro não passaria pela cabeça do consumidor hipotético. Porém, alertam para o fato de que essa falta de consciência social, de "ajuda ao próximo", poderia lhe trazer consequências ruins no futuro, e que, com o passar do tempo, o mal que este estaria causando a terceiros hoje voltaria contra ele de outras formas futuramente, tanto em vida, quanto em morte, quando ele precisasse "prestar contas para o Senhor". Essa ideia se mostrou clara com as entrevistadas 5 e 25 : 
"Tá fazendo o que colhe... ela tá plantando, um dia ela vai colher o erro que ela fez. Nada disso vai ser em vão que ela tá fazendo."

"O que ele (consumidor hipotético) faz aqui, aqui se paga. Não adianta querer o que não é seu. (...) Não adianta querer se dar bem em cima de ninguém, porque você só tá se dando mal."

Foi possível observar por meio das falas dos entrevistados que a religião consegue orientar e qualificar condutas externas, manejando, por consequência, a subjetividade desses indivíduos. Dessa forma, atitudes, comportamentos, e rituais, como, por exemplo, orações, louvores, sacramentos, promessas, e, no caso brasileiro principalmente, erros e pecados, produzem assim uma modelagem de vida, que tem como resultado a junção inerente de religião e cultura (SANCHIS, 2008; SETTON, 2008).

A religião possui uma relação com a totalidade, gerando explicações globais, ainda que sejam a partir de comparações metafóricas (SANCHIS, 2008). Considerando o vetor social, pode-se observar que culturas distintas são caracterizadas por religiões tão distintas quanto. É possível constatar, com isso, que padrões de vivência e o balizamento ético são altamente influenciados pela religião (PIERUCCI, 2006; SANCHIS, 2008).

Pesquisas anteriores sugerem que consumidores têm preocupação em não serem vistos como 'malandros' quando desejam fazer uma reclamação verídica a empresas acerca de um produto defeituoso (CHAUVEL, 2000). Isso pode ajudar a explicar o motivo de os entrevistados pensarem que atos fraudulentos são condenáveis. Porém, o que os entrevistados da presente pesquisa mostram é algo que vai além disso. Não há somente uma preocupação em ser classificado por outros como alguém de má índole. Há também uma significativa preocupação com possíveis retaliações "do Divino" com os erros cometidos durante a vida, o que pode influenciar, portanto, em sua visão sobre o consumidor hipotético e as reclamações fraudulentas.

A importância da religião na vida desse grupo de entrevistados acaba demonstrando uma preocupação mais latente em realmente não querer ser visto como "desonesto" ou "aproveitador", que pode ser observado pela fala da entrevistada 23: "A única coisa que eu falo assim, "não faz isso que isso é errado, que Deus tá vendo, ele cobra"”.

\section{CONSIDERAÇÕES FINAIS}


Este trabalho teve como objetivo investigar de que forma aspectos relacionados a características da cultura brasileira influenciam os motivos pelos quais consumidores concordam ou discordam da prática de reclamações fraudulentas. Para isso, realizou-se uma pesquisa qualitativa, pautada na técnica projetiva, baseando-se nas motivações que influenciam reclamações fraudulentas analisadas por Reynolds \& Harris (2005). A partir da análise dos dados, algumas considerações finais podem ser feitas.

A literatura de marketing que discute reclamações fraudulentas pouco analisa como aspectos da cultura de uma sociedade pode influenciar nesse tipo de comportamento (PARK; KIM; O’NEILL, 2014). A presente pesquisa, entretanto, mostra uma perspectiva diferente para essa questão, ao indicar diversas características da cultura brasileira que permeiam as opiniões de consumidores sobre esse tipo de queixa. Uma explicação para isso pode estar relacionada ao fato de inúmeros traços da cultura brasileira balizarem condutas tidas como certas e erradas diante da compreensão individual de cada cidadão (DAMATTA, 1989), de forma que os consumidores brasileiros se baseiam em tais valores para se guiarem ao longo de seus julgamentos, ações e escolhas. Assim, enquanto que em alguns momentos concordam com reclamações fraudulentas, pois enxergam na conduta empresarial algo que fere seus princípios morais, ou que o consumidor tem 'motivo' ou 'razão' para tal ato, em outros momentos discordam desse tipo de queixa, visto que vão contra seu entendimento de honra e preservação do próximo, ou mesmo com a instituição que sai em desvantagem.

Dessa forma, a presente pesquisa contribui para a teorização sobre reclamações fraudulentas ao mostrar a influência de características culturais sobre as motivações que estão associadas a esse comportamento. Embora o trabalho de Reynolds e Harris (2005) seja um marco para esse campo de estudo, pois solidificou o entendimento das motivações por trás de reclamações fraudulentas, não se propõe a explicar os elementos que ajudam a moldar tais motivações. Aceitando-se que cultura está intrinsicamente associada a valores, e que esses, por sua vez, influenciam motivações de consumidores (HENRY, 1976), é possível entender que, para mais bem conhecer o que leva consumidores a se engajar com reclamações fraudulentas, é preciso analisar a cultura que baliza seus princípios.

Em uma cultura tal como a brasileira, permeada por características relacionadas a, por exemplo, "malandragem" e "jeitinho brasileiro", que influenciam comportamentos individuais ao buscar reduzir assimetrias sociais, mas também driblar leis e normas (DAMATTA, 1986; 1989), não é de se estranhar que tais valores possam se associar à visão de consumidores quanto a reclamações (CHAUVEL, 2000). Ao trazer à luz tal relação, o presente estudo ajuda 
a solidificar o poder de explicação da teorização sobre reclamações fraudulentas ao agregar outro importante elemento que precisa ser considerado quando se busca entender o que leva um consumidor a agir de tal forma.

Discussões sobre reclamações fraudulentas em marketing tendem a ser marginais em relação a debates que buscam entender melhor a insatisfação de consumidores ou, mais ainda, quando comparadas a estudos sobre a satisfação (DAY; PERKINS, 1992). Todavia, entender melhor esse fenômeno faz-se importante para marketing pois coloca em questão a lógica dominante da área de que o consumidor tem sempre a razão. Por essa perspectiva, o consumidor, assim como a empresa, também está sujeito a agir de maneira equivocada em relação à outra parte.

É difícil, entretanto, conseguir precisar quando um consumidor irá agir de forma fraudulenta ou quais são as suas motivações por trás de tais comportamentos (REYNOLDS; HARRIS, 2005). Porém, é possível entender melhor aspectos culturais de uma sociedade e o quanto essa abriga condutas que nem sempre sejam as mais alinhadas com normas éticas - ou, mesmo, legais. Na realidade brasileira, a presença das diversas características da cultura local discutidas aqui joga a sociedade em uma dúvida coletiva pois, por mais que sejam claros os vários aspectos positivos de tais traços culturais, em casos como o do presente estudo as chances de serem priorizados desejos individuais sobre os coletivos ganham mais destaque, o que pode significar, em relação ao fenômeno aqui analisado, priorizar as vontades de um consumidor sobre os demais.

Mesmo que a análise aqui realizada mostre traços e particularidades da cultura nacional, não se deve considerar que a presença de tais referências culturais em discursos de consumidores que reclamam fraudulentamente seja exclusiva do Brasil. Em outras sociedades, o mesmo também já vem sendo analisado, ajudando a entender melhor os motivos pelos quais consumidores concordam ou discordam com a prática de reclamações fraudulentas. Na China, por exemplo, o surgimento de "reclamadores profissionais", que se especializam em realizar queixas dessa natureza, vem sendo associado a comportamentos desviantes à cultura local de enfatizar a confiança e o relacionamento pessoal nas relações pessoais (OGBORNE; JIAWEN, 2017).

Diante do que foi discutido, entende-se que é necessário haver preocupações entre empresas em conhecer melhor o fenômeno de reclamações fraudulentas e como essas podem influenciar negativamente seus processos internos. As falsas críticas sobre um produto ou serviço podem demandar uma mudança que, na prática, não seria necessária, investindo 
tempo e dinheiro na solução de um problema que, na verdade, não existe. Para evitar isso, seria importante, por exemplo, manter um banco de dados em relação a reclamações e feedbacks de consumidor sobre produtos e serviços. Isso permitirá haver uma compreensão verdadeira de consumidores e seus níveis de satisfação, já que o meio empresarial tem empreendido esforços para incentivar clientes a expressarem suas opiniões, a fim de traçar perfis e melhorias. Sugere-se, também, que empresas executem uma política de trocas e devoluções bem elaborada e um cruzamento com um banco de dados que evite que um mesmo consumidor realize reclamações por diferentes meios, e dê feedbacks falsos.

A presente pesquisa é o início para começar a entender melhor a relação entre características culturais e reclamações fraudulentas. Seus resultados ajudam a chegar a uma melhor compreensão do tema ao ilustrar como questões culturais podem influenciar de diversas maneiras condutas tidas como antiéticas. Todavia, seus achados ainda são limitados quanto ao esgotamento de conhecimento sobre o tema. Pesquisas futuras, portanto, são incentivadas.

Um caminho recomendável a ser explorado é analisar os efeitos pesquisados neste trabalho em contextos mais diversificados, tais como outras cidades, visto que o Brasil é um país de dimensões continentais e possui inúmeras outras características culturais ao longo de sua extensão, podendo até possuir outras interpretações e outros resultados a partir dessas mesmas características, além de outros países. A utilização de formulários que também contemplassem situações não oportunistas também seria importante, visto que os respondentes podem ter se sentido pressionados a discordarem de alguma das situações apresentadas. No mais, a técnica projetiva, apesar de falar de um comportamento de terceiros e dar liberdade para o entrevistado discutirem sobre situações em que consumidores não se sentiriam confortáveis em falar abertamente, pode ter sofrido um viés de comportamento politicamente correto nas avaliações feitas pelos entrevistados. Mediante isso, é apontado que sejam realizadas entrevistas em profundidade com pessoas que concordarem em falar abertamente sobre casos de reclamações fraudulentas que tenham vivenciado. Por fim, o fato de a pesquisa ser de natureza qualitativa acaba limitando alguns dos achados sobre o tema, e, portanto, sugere-se que futuros estudos adotem metodologias quantitativas para dar prosseguimento à introdução dos resultados aqui apresentados.

\section{REFERÊNCIAS}


ALMEIDA, Alberto Carlos. A Cabeça do Brasileiro. 1. ed. Rio de Janeiro: Record, v. 1, 2015.

BAKER, Melissa A.; MAGNINI, Vincent P.; PERDUE, Richard R. Opportunistic customer complaining: Causes, consequences, and managerial alternatives. International Journal of Hospitality Management, v. 31, n. 1, p. 295-303, 2012.

BARBOSA, Livia. O Jeitinho Brasileiro. 1. ed. Rio de Janeiro: Editora Campos, 1992.

BEMFICA, Melina Macedo. Jeitinho Brasileiro: entre a expressão cultural e o sinal de atraso. In: LONGO, ANA CAROLINA FIGUEIRÓ (Org.). Diálogos entre direito e sociologia: construindo pontes necessárias. $1^{\text {a }}$ ed. Brasilia: IDP, 2015. p. 51-60.

BRAGA, Sergio; BEZERRA, Eudes. O Jeitinho Brasileiro: As pequenas corrupções diárias e seus reflexos na morosidade da justiça. Revista de Politica Judiciaria, Gestão e Administração da Justiça, v. 3, n. 1, p. 17-33, 2017.

CAHILL, Dennis J. When to use qualitative methods: A new approach. Marketing Intelligence \& Planning, v. 14, n. 6, p. 16-20, 1996.

CHAUVEL, Marie Agnes. Consumidores Insatisfeitos: uma oportunidade para as empresas. $1^{\mathrm{a}}$ ed. Rio de Janeiro: Mauad, 2000.

CRISTINO, Leandro Nascimento. A Malandragem como Emblema Nacional. SOLETRAS, v. IX, n. 17, p. 39-51, 2009.

DAHL, Andrew; PELTIER, Jimmy. A historical review and future research agenda for the field of consumer satisfaction, dissatisfaction, \& complaining behavior. Journal of Consumer Satisfaction, Dissatisfaction and Complaining Behavior, v. 28, n. 2012, p. 323, 2015.

DAMATTA, Roberto. A casa e a rua. Social Anthropology, v. 8, n. 2, p. 209-211, 2000.

DAMATTA, Roberto. Carnavais, Malandros e Heróis: para uma sociologia do dilema brasileiro. $6^{\text {a }}$ edição ed. Rio de Janeiro: Rocco, 1983.

DAMATTA, Roberto. O que faz o brasil, Brasil? [S.l: s.n.], 1989.

FLACH, Leonardo. O jeitinho brasileiro: Analisando suas características e influências nas práticas organizacionais. Revista Gestão e Planejamento, v. 12, n. 3, p. 499-514, 2012.

GAGLIETTI, M. O poder simbólico e a distância entre os dois Brasis: o formal e o informal. Revista Katálysis, v. 9, n. 1, p. 43-52, 2006.

GOVERNO FEDERAL. Aumentam os atendimentos em portal do Consumidor. Disponível em: https://www.justica.gov.br/news/collective-nitf-content-1551466308.51. Acesso em 12 dezembro, 2019.

GUEST, Greg; BUNCE, Arwen; JOHNSON, Laura. How Many Interviews Are Enough?: An 
Experiment with Data Saturation and Variability. Field Methods, v. 18, n. 1, p. 59-82, 2006.

GUMMESSON, Evert. Qualitative research in marketing: Road-map for a wilderness of complexityand unpredictability. European Journal of Marketing, v. 39, n. 3/4, p. 309-327, 2005 .

HARRIS, Lloyd C.; REYNOLDS, Kate L. The Consequences of Dysfunctional Customer Behavior. Journal of Service Research, v. 6, n. 2, p. 144-161, 2003.

HEMAIS, Marcus Wilcox; CASOTTI, Leticia Moreira. Insatisfações projetadas de consumidores de baixa renda. Revista Pensamento Contemporâneo em Administração, v. 8, n. 4, p. 65-84, 2014..

HEMAIS, Marcus Wilcox; CASOTTI, Leticia Moreira. Por que Reclamar? Melhoria de autoestima e cidadania de um grupo de baixa renda a partir dos serviços de uma agência de defesa do consumidor. REAd - Revista Eletrônica de Administração, v. 86, n. 2, p. 83-109, 2017.

HENRY, Walter. Cultural values do correlate with consumer behavior. Journal of Marketing Research, v.13, n.2, p.121-127, 1976.

HUANG, Zhuowei (Joy); MIAO, Li. Illegitimate Customer Complaining Behavior in Hospitality Service Encounters: A Frontline Employee Perspective. Journal of Hospitality and Tourism Research, v. 40, n. 6, p. 655-684, 2013.

KING, Tamira; DENNIS, Charles. Unethical consumers: Deshopping behaviour using the qualitative analysis of theory of planned behaviour and accompanied (de)shopping. Qualitative Market Research: An International Journal, v. 9, n. 3, p. 282-296, 2006.

LAMEIRA, Valdir; BERTRAND, Hélène. Ethics, corruption, governance and emerging markets. REAd - Revista Eletrônica de Administração, v. 14, n. 1, p. 1-24, 2008.

LOURENÇO, Cléria. Cultura Brasileira e Marketing de Relacionamento: Um Estudo Etnográfico no Varejo. Brazilian Journal of Marketing, v. 13, n. 5, p. 47-64, 2014.

MELO, Jaqueline Silva; VALE, Glaucia Maria; CORRÊA, Victor Silva. Sobrevivência e Mortalidade das Atividades Produtivas no Segmento de Baixa Renda. REAd - Revista Eletrônica de Administração, v. 24, n. 3, p. 130-154, 2018.

MOLINA, Ana Carolina; PEPECE, Olga Maria Coutinho. Plataforma "Reclame Aqui" e o comportamento dos consumidores entre os anos de 2014 até 2016". Métodos e Pesquisa em Administração, v. 3, n. 1, p. 5-14, 2018.

MOTTA, Fernando C Prestes; ALCADIPANI, Rafael. Jeitinho Brasileiro , Controle Social e Competição. Revista de Administração de Empresas, v. 39, n. 1, p. 6-12, 1999. 
OGBORNE, Junni. and JIAWEN, Ma. The rise and fall of the "professional complainer". AmCham China. 8 nov., 2017. Disponível em: https://www.amchamchina.org/news/the-riseand-fall-of-the-professional-complainer. Acesso em: 14 dez., 2019.

PARK, Seul Gi; KIM, Kyungmi; O’NEILL, Martin. Complaint behavior intentions and expectation of service recovery in individualistic and collectivistic cultures. International Journal of Culture, Tourism, and Hospitality Research, v. 8, n. 3, p. 255-271, 2014.

PIERUCCI, Antônio Flávio. Religião como solvente - uma aula. Novos Estudos - CEBRAP, n. 75, p. 111-127, 2006.

PIRON, Francis; YOUNG, Murray. Retail borrowing: Insights and implications on returning used merchandise. International Journal of Retail \& Distribution Management, v. 28, n. 1, p. 27-36, 2000.

PRADO, Alyssa. O Jeitinho Brasileiro: Uma Revisão Bibliográfica. Horizonte Científico, v. 10, n. 1, p. 1808-3064, 2016.

RÉVILLION, Anya Sartori Piatnicki. A Utilização de Pesquisas Exploratórias na Área de Marketing. RIMAR- Revista Interdisciplinar de Marketing, v. 2, n. 2, p. 21-37, 2003.

REYNOLDS, Kate L.; HARRIS, Lloyd C. When service failure is not service failure: an exploration of the forms and motives of "illegitimate" customer complaining. Journal of Services Marketing, v. 19, n. 5, p. 321-335, 2005.

ROCHA, Gilmar. "Eis o malandro na praça outra vez": a fundação da discursividade malandra no Brasil dos anos 70. SCRIPTA, v. 10, n. 9, p. 108-121, 2006.

ROSENBAUM, Mark; KUNTZE, Ronald. The Relationship between Anomie and Unethical Retail Disposition. Psychology and Marketing, v. 20, n. 12, p. 1067-1093, 2003.

ROSENBAUM, Mark; KUNTZE, Ronald; WOOLDRIDGE, Barbara. Understanding Unethical Retail Disposition Practice and Restraint from the Consumer Perspective. Psychology \& Marketing, v. 28, n. 1, p. 29-52, 2011.

RUBIN, Herbert J.; RUBIN, Irene S. Qualitative Interviewing: The Art of Hearing Data. $2^{\text {nd }}$ ed. Thousand Oaks, CA: SAGE Publications, 2005.

SANCHIS, Pierre. Cultura Brasileira e Religião... Passado e Atualidade. Cadernos CERU, v. 19, n. 2, p. 71-92, 2008.

SCHMIDT, Ruth A et al. Deshopping - the art of illicit consumption. International Journal os Retail \& Distribution Management, v. 27, n. 8, p. 290-301, 1999.

SECRETARIA NACIONAL DO CONSUMIDOR. Boletim Sindec 2011. Disponível em: https://www.justica.gov.br/seus-direitos/consumidor/sindec/anexos/boletim-sindec2011.pdf/view. Acesso em 12 dezembro, 2019.

SECRETARIA NACIONAL DO CONSUMIDOR. Boletim Sindec 2018. Disponível em: https://www.justica.gov.br/seus-direitos/consumidor/sindec/anexos/boletim-sindec- 
2018.pdf/view. Acesso em 12 dezembro, 2019.

SETTON, Maria da Graça Jacintho. As religiões como agentes da socialização. Cadernos CERU, v. 19, n. 2, p. 15-25, 2008.

VIEIRA, Clóvis Abreu; COSTA, Frederico Lustosa Da; BARBOSA, Lázaro Oliveira. O jeitinho brasileiro como um recurso de poder. Revista de Administração Pública, v. 16, n. 2, p. 5-31, 1982.

WILL, Valerie; EADIE, Douglas; MACASKILL, Susan. Projective and enabling techniques explored. Marketing Intelligence \& Planning, v. 14, n. 6, p. 38-43, 1996.

WIRTZ, Jochen; KUM, Doreen. Consumer Cheating on Service Guarantees. Journal of the Academy of Marketing Science, v. 32, n. 2, p. 159-175, 2004. 